\title{
Clinicopathological and prognostic significance of HER-2/neu and VEGF expression in colon carcinomas
}

\author{
Qingguo $\mathrm{Li}^{1}$, Daorong Wang ${ }^{1}$, Jing $\mathrm{Li}^{2}$ and Ping Chen ${ }^{1 *}$
}

\begin{abstract}
Background: HER-2/neu and VEGF expression is correlated with disease behaviors in various cancers. However, evidence for their expression in colon cancer is rather contradictory both for the protein expression status and prognostic value. HER-2/neu is found to participate in VEGF regulation, and has known correlation with VEGF expression in some tumors. In this study, we investigated HER-2/neu and VEGF expression in Chinese colon patients and explored whether there was any correlation between their expression patterns.
\end{abstract}

Methods: HER-2/neu and VEGF were investigated immunohistochemically using tumor samples obtained from 317 colon cancer patients with all tumor stages. Correlation of the degree of staining with clinicopathological parameters and survival was investigated.

Results: Positive expression rates of HER-2/neu and VEGF in colon cancer were $15.5 \%$ and $55.5 \%$ respectively. HER-2/neu expression was significantly correlated with tumor size and distant metastases $(P<0.05)$, but was not an independent prognostic marker of survival $(P>0.05)$. Expression of VEGF was significantly correlated with tumor size, tumor stage, lymph node metastases, and distant metastases $(P<0.05)$. The 5 -year survival rate in patients with negative and positive VEGF expression was $70.2 \%$ and $61.9 \%$ respectively; the difference was not statistically significant $(P=0.146)$. No correlation between HER-2/neu and VEGF expression was detected $(P=0.151)$.

Conclusions: HER-2/neu and VEGF are not important prognostic markers of colon cancer. The present results do not support any association between HER2/neu and VEGF expression in this setting.

\section{Background}

Colorectal cancer (CRC) is one of the most common malignancies worldwide and is the fourth leading cause of cancer-related death in China. Although the development of new cytotoxic agents such as oxaliplatin and irinotecan and new surgical techniques has improved prognosis of CRC, once patients develop resistance to chemotherapeutic regimens no other treatment options are available. Recently, therapeutic strategies have been improved by the development and availability of monoclonal antibodies. Investigators have recently been evaluating biologic and molecular targets for their possible roles as prognostic markers and as targets for therapy.

\footnotetext{
* Correspondence: chen86ky@126.com

'Department of General Surgery, First Clinic Medical School of Yangzhou University, Yangzhou, China

Full list of author information is available at the end of the article
}

The HER-2/neu oncogene, also known as c-erbB-2, encodes a transmembrane tyrosine kinase receptor, homologous to epidermal growth factor receptor (EGFR), This receptor is involved in the growth and progression of malignant cells. For instance, overexpression of the HER-2/neu is detectable in $25 \%-35 \%$ of breast cancers [1-3]. Treatment of these patients with trastuzumab (Herceptin), an anti-HER-2/neu monoclonal antibody, has been shown to reduce tumor volume, magnify the effects of chemotherapy, and increase survival rate in primary and metastatic breast cancer $[4,5]$. The success of anti-HER-2/neu therapy in breast cancer has led to evaluations of HER-2/neu expression in multiple tumors, colon cancer among them, but conflicting data exist with reports of its expression in CRC ranging at $0-80 \%[6-8]$.

Vascular endothelial growth factor (VEGF)-A, formerly known as VEGF, is an angiogenic factor that is 
produced by tumor cells to stimulate intratumoral microvessel proliferation (neoangiogenesis). Tumor angiogenesis contributes to the metastatic process by promotion of leaking blood vessels for vascular invasion $[9,10]$. VEGF expression has been shown to be upregulated in many tumors and to be of prognostic value [11-13]. Furthermore, treatment with bevacizumab, a monoclonal antibody against VEGF, in combination with chemotherapy results in significant improvements in overall survival and progression-free survival compared with chemotherapy alone [14-16]. In addition, recently HER-2/neu was found to participate in and be correlated with VEGF expression [17-20]. However, no previous studies have clarified their associations in colon cancer. The purposes of this study were to examine expression status of HER-2/neu and VEGF in colon cancer and to evaluate whether their expression levels are correlated with each other and with clinicopathological parameters and prognosis.

\section{Methods}

Between January 2000 and December 2005, a total of 317 patients received elective surgery for colon cancer at the Department of General Surgery of First Clinic Medical School of YangZhou University. The patients comprised 187 men and 130 women aged 21-86 (mean 57.8) years. No patient received anticancer treatment prior to surgery. Patients' clinicopathologic parameters including sex, age, and tumor differentiation, location, and pTNM pathological classification according to the International Union Against Cancer (UICC) were collected.

\section{Immunohistochemistry}

Immunohistochemical analysis for HER-2/neu and VEGF expression was performed on formalin-fixed paraffin-embedded sections of surgical specimens. The slides were deparaffinized in xylene and rehydrated in ethanol solution. Endogenous peroxidase was blocked with $0.3 \% \mathrm{H}_{2} \mathrm{O}_{2}$ in methanol for $10 \mathrm{~min}$. The slides were immersed in $10 \mathrm{~mm}$ citric buffer ( $\mathrm{pH}$ 6.0) with heating for $15 \mathrm{~min}$ for antigen retrieval, then cooled at room temperature for $20 \mathrm{~min}$ and washed with phosphate-buffered saline (PBS). Nonspecific binding was blocked by preincubation with $10 \%$ fetal calf serum in PBS with $0.01 \%$ sodium azide then the slides were incubated in a humidifier chamber for $1 \mathrm{~h}$ with antibody against VEGF(titer 1:50; Dako Cytomation, Denmark) and HER-2/neu HercepTest ${ }^{\mathrm{TM}}$ kit (titer 1:100;Dako Cytomation, Denmark). After washing three times in PBS, the slides were incubated with the envision-HrP complex (undiluted; Dako) for $60 \mathrm{~min}$ then visualized with diaminobenzidine and counterstained with hematoxylin. For substitute negative controls, the primary antibody was replaced with PBS. Positive controls included breast cancer tissue known to exhibit high levels of marker.

\section{Scoring systems}

The slides were assessed by two pathologists with minimal interobserver variability including resolution of observed differences by simultaneous reevaluation. HER-2/neu staining was scored semiquantitatively according to the following scoring system approved by the US Food and Drug Administration (FDA): 0, no immunostaining or membrane staining in $<10 \%$ of the tumor cells; $1+$, incomplete membrane staining of $>10 \%$ of tumor cells; $2+$, weak-to-moderately complete membrane staining of $>10 \%$ of tumor cells; $3+$, a moderate-to-strongly complete membrane staining of $>10 \%$ of tumor cells. Scores of 0 or $1+$ indicated a tumor negative for HER-2/neu expression, and scores of 2 + and 3+ were regarded as positive expression of HER-2/ neu.VEGF was graded according to previously established criteria [21]. A positive result constituted $>10 \%$ of cells stained, and a negative result constituted $<10 \%$ of cells stained. Intensity of staining was graded on a scale of 0 to $3+$, with $3+$ representing the strongest staining.

\section{Follow-up}

Patients underwent continuous follow-up as of January 2011. No patient was lost to follow-up. The median follow-up interval was 68.8 months.

\section{Statistics}

The results were analyzed using the statistical software package SPSS for Windows, version 13 (SPSS, USA). Association of HER-2/neu and VEGF staining with clinicopathological parameters was analyzed by $\chi 2$ test. Overall survival curves were calculated using the method of Kaplan and Meier, differences between the curves were analyzed by log-rank test. Statistical significance was set at $P<0.05$.

\section{Results}

\section{Expression of HER-2/neu and VEGF}

HER-2/neu expression was positive in 49 of 317 colon cancer samples $(15.5 \%)$ and negative in the remaining 268 samples $(84.5 \%)$, only seven samples were strongly positive. VEGF expression was positive in 176 of 317 colon cancer samples (55.5\%) and negative in the remaining 141 samples (44.5\%), 46 samples $(14.5 \%)$ were $1+, 79$ (24.9\%) were $2+$, and 51(16.1\%) were $3+$. Figure 1 shows HER-2/neu and VEGF staining patterns in colon cancer.

\section{Association between HER-2/neu and VEGF}

HER-2/neu was detectable in 31 of 176 (17.6\%) patients with VEGF-positive expression, in contrast to 18 of 141 (12.8\%) patients with VEGF-negative expression (Table 1); the difference was not statistically significant. 


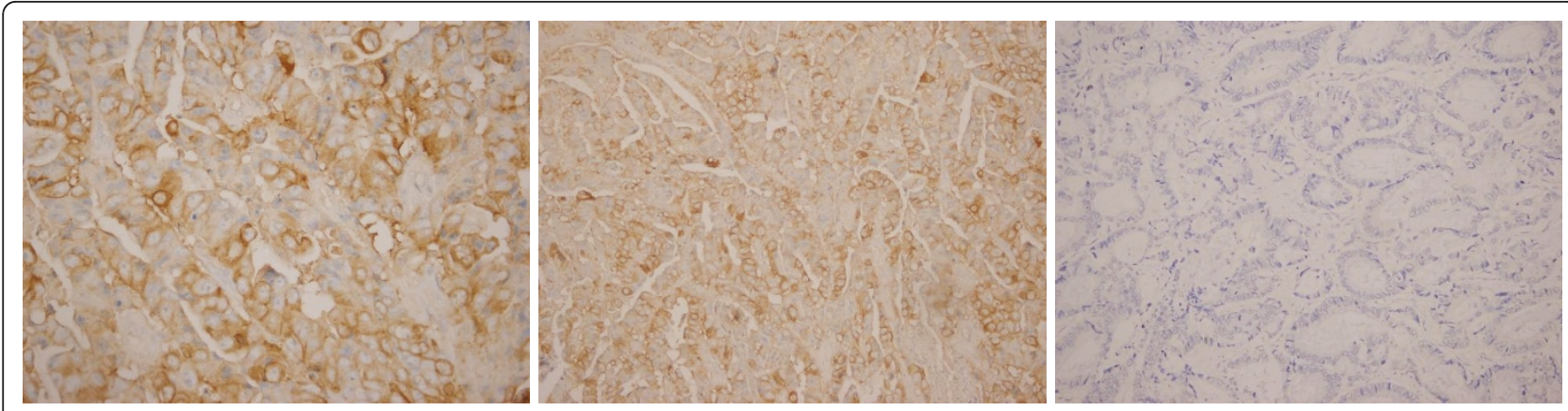

Figure 1 Immunohistochemical staining for HER-2/neu and VEGF (original magnification, $\times \mathbf{2 0 0}$ ). (a) Strong cytoplasmic stain in $>10 \%$ of tumor cells. (b) VEGF stained in > 10\% of tumor cells. (c) No expression of VEGF and c-erbB-2 in colon cancer.

\section{Correlation of molecular markers and clinicopathological features}

Correlations of HER-2/neu and VEGF in colon cancer with clinical features are shown in Table 2. HER-2/neu expression correlated with tumor size and distant metastases (both $P<0.05$ ), but not with other clinicopathological features assessed (all $P>0.05$ ). Expression of VEGF correlated with tumor size, $\mathrm{T}$ stage, lymph node metastases and distant metastases (all $P<0.05$ ). Statistical evaluation of VEGF expression according to age, sex, tumor location, differentiation grade, and perineural invasion revealed no significant difference among these variables (all $P>0.05$ ).

\section{Survival analysis}

All patients underwent follow-up until cancer-related death or $>5$ years after tumor resection. The 5 -year survival of HER-2/neu-positive patients was $63.3 \%$, and did not differ significantly from that of HER-2/neunegative individuals $(66.0 \% ; \chi 2=0.062, P=0.804)$. The 5 -year survival for patients with negative and positive VEGF expression was $70.2 \%$ and $61.9 \%$ respectively, with a tendency of shorter survival in the latter versus former group, although the difference was not statistically significant $\left(\chi^{2}=2.114, P=0.146\right)$.

\section{Discussion}

HER-2/neu is a proto-oncogene that encodes a transmembrane protein with tyrosine kinase activity and is closely related to but biologically distinct from EGFR. Amplification and overexpression of the HER-2/neu

Table 1 Relation between HER-2/neu and VEGF expression

\begin{tabular}{|c|c|c|c|c|c|}
\hline \multirow[t]{2}{*}{ VEGF } & \multirow[t]{2}{*}{ expression } & \multirow{2}{*}{$\frac{\text { HER-2/neu }}{\text { Positive }}$} & \multirow{2}{*}{$\begin{array}{c}\text { expression } \\
\text { Negative }\end{array}$} & \multirow[t]{2}{*}{ Total } & \multirow[t]{2}{*}{$P$-value } \\
\hline & & & & & \\
\hline Positive & & 31 & 145 & 176 & \\
\hline Negative & & 18 & 123 & 141 & 0.151 \\
\hline
\end{tabular}

gene have been demonstrated in several tumors such as breast, stomach, lung, and urinary bladder. The frequency of positivity appears to increase with clinical stage of disease and is associated with a worse prognosis [22-24]. Although Her-2/neu has been postulated as a prognostic biological marker for colorectal caner, conflicting data exist about the prevalence of HER-2/neu overexpression in CRC as well as its relationship with prognosis. We examined 317 colon cancer samples for the presence of Her-2/neu oncoprotein by immunohistochemistry. In all, 49 samples (15.5\%) showed positive expression of Her-2/neu; only 7 samples were strongly membrane positive. Similar results were described in the study of Kavanagh et al.[25] They examined HER-2/ neu protein expression in 132 CRC specimens, and found HER-2/neu overexpression in $11 \%$, with 2 displaying were strong membranous immunostaining[25]. Our research showed that HER-2/neu expression was related with tumor size and distant metastases, suggesting that this protein may participate in tumor growth and distant metastasis although it was not a significant index of survival.

Previous reports that have demonstrated associations between HER-2/neu protein expression and more aggressive colorectal tumors. Demirbas et al [26] reported an association between HER-2/neu overexpression and tumor size $(>5 \mathrm{~cm})$, differentiation grade, and vascular and lymphatic invasion. Besides, their patients with HER-2/neu protein-positive expression had shorter disease-free survival and overall survival compared with those who were negative. They suggested that overexpression of HER-2/neu protein played an important role in the progression of CRC and was considered an independent prognostic indicator. On the other hand, Jesus et al [27] reported that the HER-2/neu expression was not correlated with sex, age, tumor differentiation, localization of the primary tumor and overall survival. They indicated that HER-2/neu expression was unlikely to play a major role in the therapeutic management of colorectal cancer. 
Table 2 Clinicopathological variables and their correlation with immunohistochemical expression of HER-2/neu and VEGF

\begin{tabular}{|c|c|c|c|c|c|c|c|}
\hline \multirow[t]{2}{*}{ Variable } & \multirow[t]{2}{*}{ Patients } & \multicolumn{2}{|c|}{ HER-2/neu } & \multirow[t]{2}{*}{$P$-value ${ }^{a}$} & \multicolumn{2}{|l|}{ VEGF } & \multirow[t]{2}{*}{$P$-value ${ }^{a}$} \\
\hline & & Positive & Negativ & & Positive & Negative & \\
\hline Sex & & & & 0.553 & & & 0.438 \\
\hline Male & 187 & 29 & 158 & & 105 & 82 & \\
\hline Female & 130 & 20 & 110 & & 71 & 59 & \\
\hline Age & & & & 0.525 & & & 0.817 \\
\hline$\leq 60$ & 195 & 28 & 167 & & 107 & 88 & \\
\hline$>60$ & 122 & 21 & 101 & & 69 & 53 & \\
\hline Tumor size (cm) & & & & 0.004 & & & 0.000 \\
\hline$<5 \mathrm{~cm}$ & 211 & 23 & 183 & & 95 & 111 & \\
\hline$\geq 5 \mathrm{~cm}$ & 106 & 26 & 85 & & 81 & 30 & \\
\hline Differentiation grade & & & & 0.193 & & & 0.451 \\
\hline Well & 90 & 10 & 80 & & 55 & 35 & \\
\hline Moderate & 152 & 23 & 129 & & 81 & 71 & \\
\hline Poor & 75 & 16 & 59 & & 40 & 35 & \\
\hline T stage & & & & 0.166 & & & 0.177 \\
\hline $\mathrm{T} 1 \sim \mathrm{T} 2$ & 97 & 11 & 86 & & 48 & 49 & \\
\hline T3 T4 & 220 & 38 & 182 & & 128 & 92 & \\
\hline Lymph node status & & & & 0.460 & & & 0.119 \\
\hline Negative & 167 & 25 & 142 & & 87 & 80 & \\
\hline Positive & 150 & 24 & 126 & & 89 & 61 & \\
\hline Distant metastasis & & & & $0.010^{b}$ & & & 0.017 \\
\hline MO & 291 & 40 & 251 & & 156 & 135 & \\
\hline M1 & 26 & 9 & 17 & & 20 & 6 & \\
\hline Perineural invasion & & & & $0.127^{b}$ & & & 0.232 \\
\hline Negative & 299 & 44 & 255 & & 168 & 131 & \\
\hline Positive & 18 & 5 & 13 & & 8 & 10 & \\
\hline
\end{tabular}

a Pearson $\chi^{2}$ test

${ }^{\mathrm{b}}$ Adjusted $\chi^{2}$ test

There are several possible reasons for discrepancies between studies to date. The most likely reason for the divergent findings is the different scoring systems-for example, Uner et al[28] judged only membrane staining in $>20 \%$ of tumor cells to be positive. The inclusion of cytoplasmic positivity in some papers may also be responsible for the conflicting results, because there is relatively high percent of positive cytoplasmic staining in CRC. Sensitivity of the antibodies used also makes the comparison between studies very challenging; the HercepTest ${ }^{\mathrm{TM}}$ kit (Dako) is the only antibody recommended by the FDA for HER-2/neu examination. Different antibodies may lead to different results, Park et al [23] reported a $47 \%$ protein expression rate using a polyclonal antibody (Zymed, South San Francisco, USA) and correlated overexpression with a higher incidence of postoperative recurrence. Conversely, Schuell et al [29] demonstrated an overexpression rate of $4 \%$ that was not correlated with survival using the validated HercepTest $^{\mathrm{TM}}$ kit. Moreover, immunohistochemistry is a semiquantitative method and may easily be influenced by researchers' subjective perception. In addition, ethnic diversity of patients should be taken into account. Ghaffarzadegan et al[30] examined 69 Iranian colorectal samples and showed HER-2/neu staining in a high percent of cases with $65.9 \%$ showing cytoplasmic staining and $34.1 \%$ membranous-cytoplasmic staining and more prominent membranous staining in higher stages and grades. Kavanagh et al[25] detected that HER-2/neu protein was overexpressed in only $11 \%$ of Irish CRC patients, and found no correlation with tumor grade, Dukes' stage, time to recurrence and 5-year survival.

Angiogenesis represents an important event in the process of tumor invasion and metastases, and it is well established that VEGF is one of the most important molecules promoting endothelial cell migration, proliferation, and differentiation [31,32]. In our study, VEGF expression was noted in more than half of colon cancers $(55.5 \%)$. Both the incidence and proportion of VEGF expression increased with the progression of colorectal carcinogenesis classified by depth of tumor invasion, presence of lymph node metastases and distant 
metastases, consistent with prior studies reported by Takahashi et al[33] and Kang et al[34]. Patients with positive VEGF expression had a tendency of shorter overall survival, although the difference versus negative patients was nonsignificant, suggesting that VEGFpositive phenotype in colon cancer may not provide additional prognostic value. This result is consistent with that of Lee et al [35]. In contrast, Kang et al [34] found that immunohistochemical expression of VEGF was an independent prognostic factor for CRC patients.

VEGF is one of the most potent inducers of angiogenesis, whereas HER-2/neu has been implicated in the regulation of VEGF. In human breast cancer, overexpression of HER-2/neu is correlated with increased VEGF expression $[17,19]$. Klos et al $[20]$ demonstrated that HER-2/neu activation led to translational upregulation of VEGF and increased angiogenesis through ERK, PI3K/ Akt, mTOR, and p70S6K. Petit et al [36] observed that neutralizing antibodies (trastuzumab) against HER-2/neupositive breast cancer cell lines downregulated expression of VEGF by twofold. On the other hand, trastuzumab decreased tumor VEGF expression through the PI3K/Akt pathway in HER-2/neu-positive cancer cells[11,37-39], and could also increase anti-angiogenic factor and inhibit additional pro-angiogenic factors such as transforming growth factor- $\alpha$, angiopoietin- 1 , plasminogen-activator inhibitor-1, and interleukin(IL)-8 [11,37]. Therefore, trastuzumab could exert synergistic interaction with antiVEGF monoclonal antibody to suppress tumor angiogenesis by modulation of multiple angiogenic factors. Human breast cancers overexpressing HER-2/neu may be ideal targets for dual therapy with agents that inhibit VEGF and HER-2/neu. Conversely, no correlation was found between VEGF and c-erbB-2 in squamous cell carcinoma of the head and neck [40], and there is little research on correlation of VEGF and HER-2/neu in colon cancer.

The present study showed that VEGF was higher in HER-2/neu-positive tumor specimens than in those that were negative. Meanwhile, HER-2/neu expression was greater in VEGF-positive tumor than in VEGF-negative tumor, although the difference was not statistically significant. These findings suggest that there is no apparent correlation between HER-2/neu and VEGF expression in colon cancer. Our results are similar to those of Ochs et al [41] who reported that association was not supported between HER-2/neu and VEGF expression in stage II colon cancer. In breast cancer, angiogenesis could be regulated by HER-2 pathway even in the absence of HER-2/neu overexpression, targeting downstream targets of HER-2, particulary those leading to VEGF transcription and angiogenesis, could likely produce additional antitumor effects [42]. However, whether this approach could be useful against colon cancer neovascularization deserves further research.

\section{Conclusions}

Our study aimed at evaluating the expression of c-erbB-2 and VEGF in colon cancer by immunohistochemical methods. We found HER-2/neu and VEGF is not important prognostic markers of colon cancer, and our results do not support an association between HER2/neu and VEGF expression.

\section{Acknowledgements}

We thank Dr. Yanshi Yan and Dr. Baizhou Li, Department of Pathology, Cancer Hospital, Fudan University, Shanghai, China for their technical help with the immunohistochemistry studies.

\section{Author details}

'Department of General Surgery, First Clinic Medical School of Yangzhou University, Yangzhou, China. ${ }^{2}$ Department of Medical Oncology, Second Clinic Medical School of Yangzhou University, Yangzhou, China.

\section{Authors' contributions}

PC designed the study, performed the statistical analyses and wrote the manuscript.QGL collected clinicopathological data and performed laboratory analysis. JL, DRW, QGL scored the immunostained slides, prepared the images, and reviewed the manuscript. All authors read and approved the final manuscript.

\section{Competing interests}

The authors declare that they have no competing interests.

Received: 28 August 2010 Accepted: 27 June 2011

Published: 27 June 2011

\section{References}

1. Slamon DJ, Clark GM, Wong SG, Levin WJ, Ullrich A, McGuire WL: Human breast cancer: correlation of relapse and survival with amplification of HER-2/neu oncogenes. Science 1987, 234:177-182.

2. Saranath D, Panchal RG, Nair R, Metha AR, Sanghavi VD, Deo MG: Amplification and overexpression of epidermal growth factor receptor gene in human oropharyngeal cancer. Eur J Cancer 1992, 28B:139-143.

3. Slamon DJ, Godolphin W, Jones LA, Holt JA, Wong SG, Keith DE, Levin WJ, Stuart SG, Udove J, Ullrich A, et al: Studies of the HER-2/neu protooncogene in human breast and ovarian cancer. Science 1989, 244:707-712.

4. Slamon DJ, Leyland-Jones B, Shak S, Fuchs H, Paton V, Bajamonde A, Fleming T, Eiermann W, Wolter J, Pegram M, Baselga J, Norton L: Use of chemotherapy plus monoclonal antibody against HER2 for metastatic breast cancer that overexpress HER2. N Engl J Med 2001, 344:783-792.

5. Vogel CL, Cobleigh MA, Tripathy D, Gutheil JC, Harris LN, Fehrenbacher L, Slamon DJ, Murphy M, Novotny WF, Burchmore M, Shak S, Stewart SJ, Press M: Efficacy and safety of trastuzumab as a single agent in first-line treatment of HER2-overexpressing metastatic breast cancer. J Clin Oncol 2002, 20:719-726.

6. Caruso ML, Valentini AM: Immunohistochemical p53 overexpression correlated to c-erbB-2 and cathepsin D proteins in colorectal cancer. Anticancer Res 1996, 16:3813-3818.

7. Osako T, Miyahara M, Uchino S, Inomata M, Kitano S, Kobayashi M: Immunohistochemical study of c-erbB-2 protein in colorectal cancer and the correlation with patient survival. Oncology 1998, 55:548-555.

8. Yang JL, Ow KT, Russell PJ, Ham JM, Crowe PJ: Higher expression of oncoproteins c-myc, c-erb B-2/neu, PCNA, and p53 in metastasizing colorectal cancer than in nonmetastasizing tumors. Ann Surg Oncol 1996, 3:574-579.

9. Han H, Landreneau RJ, Santucci TS, Tung MY, Macherey RS, Shackney SE, Sturgis CD, Raab SS, Silverman JF: Prognostic value of 
immunohistochemical expression of p53, HER-2/neu, and bcl-2 in stage I non-small cell lung cancer. Hum Pathol 2002, 33:105-110.

10. Han H, Silverman JF, Santucci TS, Macherey RS, d'Amato TA, Tung MY, Weyant RJ, Landreneau RJ: Vascular endothelial growth factor expression in stage I non-small cell lung cancer correlates with neoangiogenesis and a poor prognosis. Ann Surg Oncol 2001, 8:72-79.

11. Cascinu S, Staccioli MP, Gasparini G, Giordani P, Catalano V, Ghiselli R, Rossi C, Baldelli AM, Graziano F, Saba V, Muretto P, Catalano G: Expression of vascular endothelial growth factor can predict event-free survival in stage II colon cancer. Clin Cancer Res 2000, 6:2803-2807.

12. Bradbury PA, Zhai R, Ma C, Xu W, Hopkins J, Kulke MJ, Asomaning K, Wang Z, Su L, Heist RS, Lynch TJ, Wain JC, Christiani D, Liu G: Vascular Endothelial Growth Factor Polymorphisms and Esophageal Cancer Prognosis. Clin Cancer Res 2009, 15:4680-4685.

13. Schneider BP, Wang M, Radovich M, Sledge GW, Badve S, Thor A, Flockhart DA, Hancock B, Davidson N, Gralow J, Dickler M, Perez EA Cobleigh M, Shenkier T, Edgerton S, Miller KD: ECOG 2100: Association of vascular endothelial growth factor and vascular endothelial growth factor receptor-2 genetic polymorphisms with outcome in a trial of paclitaxel compared with paclitaxel plus bevacizumab in advanced breast cancer: ECOG 2100. J Clin Oncol 2008, 26:4672-4678.

14. Giantonio BJ, Catalano PJ, Meropol NJ, O'Dwyer PJ, Mitchell EP, Alberts SR, Schwartz MA, Benson AB, Eastern Cooperative Oncology Group Study E3200: Bevacizumab in combination with oxaliplatin, fluorouracil, and leucovorin (FOLFOX4) for previously treated metastatic colorectal cancer: results from the eastern cooperative oncology group study E3200. J Clin Oncol 2007, 12:1539-1544.

15. Hurwitz $H$, Fehrenbacher L, Novotny W, Cartwright T, Hainsworth J, Heim W, Berlin J, Baron A, Griffing S, Holmgren E, Ferrara N, Fyfe G, Rogers B, Ross R, Kabbinavar F: Bevacizumab plus irinotecan, fluorouracil, and leucovorin for metastatic colorectal cancer. N Engl J Med 2004, 350:2335-2342.

16. Kabbinavar FF, Schulz J, McCleod M, Patel T, Hamm JT, Hecht JR, Mass R, Perrou B, Nelson B, Novotny WF: Addition of bevacizumab to bolus fluorouracil and leucovorin in first-line metastatic colorectal cancer: results of a randomized phase II trial. J Clin Oncol 2005, 23:3697-3705.

17. Yen L, You XL, Al Moustafa AE, Batist G, Hynes NE, Mader S, Meloche S, Alaoui-Jamali MA: Heregulin selectively upregulates vascular endothelial growth factor secretion in cancer cells and stimulates angiogenesis. Oncogene 2000, 19:3460-3469.

18. Yen $L$, Benlimame $N$, Nie ZR, Xiao D, Wang $T$, Al Moustafa AE, Esumi $H$, Milanini J, Hynes NE, Pages G, Alaoui-Jamali MA: Differential regulation of tumor angiogenesis by distinct ErbB homo-and heterodimers. Mol Biol Cell 2002, 13:4029-44.

19. Yang W, Klos K, Yang Y, Smith TL, Shi D, Yu D: ErbB2 overexpression correlates with increased expression of vascular endothelial growth factors A, C, and D in human breast carcinoma. Cancer 2002, 94:2855-2861.

20. Klos KS, Wyszomierski SL, Sun M, Tan M, Zhou X, Li P, Yang W, Yin G, Hittelman WN, Yu D: ErbB2 increases vascular endothelial growth factor protein synthesis via activation of mammalian target of rapamycin/ p70S6K leading to increased angiogenesis and spontaneous metastasis of human breast cancer cells. Cancer Res 2006, 66:2028-2037.

21. D'Emilia J, Bulovas K, D'Ercole K, Wolf B, Steele G Jr, Summerhayes IC: Expression of the c-erbB-2 gene product ( $p 185)$ at different stages of neoplastic progression in the colon. Oncogene 1989, 4:1233-1239.

22. McKay JA, Loane JF, Ross VG, Ameyaw MM, Murray GI, Cassidy J, McLeod HL: c-erbB-2 is not a major factor in the development of colorectal cancer. Br J Cancer 2002, 86:568-573.

23. Park DI, Kang MS, Oh SJ, Kim HJ, Cho YK, Sohn Cl, Jeon WK, Kim BI, Han WK, Kim H, Ryu SH, Sepulveda AR: HER-2/neu overexpression is an independent prognostic factor in colorectal cancer. Int $J$ Colorectal Dis 2007, 22:491-497.

24. Baiocchi G, Lopes A, Coudry RA, Rossi BM, Soares FA, Aguiar S, Guimarães GC, Ferreira FO, Nakagawa WT: ErbB family immunohistochemical expression in colorectal cancer patients with higher risk of recurrence after radical surgery. Int J Colorectal Dis 2009, 24:1059-1068.

25. Kavanagh DO, Chambers G, O'Grady L, Barry KM, Waldron RP, Bennani F, Eustace PW, Tobbia I: Is overexpression of HER-2 a predictor of prognosis in colorectal cancer? BMC Cancer 2009, 9:1-6.
26. Demirbaş $S$, Sücüllü I, Yildirim S, Celenk T: Influence of the c-erb B-2, $\mathrm{nm} 23, \mathrm{bcl}-2$ and $\mathrm{p} 53$ protein markers on colorectal cancer. Turk $J$ Gastroenterol 2006, 17:13-19.

27. Jesus EC, Matos D, Artigiani R, Waitzberg AF, Goldenberg A, Saad SS: Assessment of staging, prognosis and mortality of colorectal cancer by tumor markers: receptor erbB-2 and cadherins. Acta Cir Bras 2005, 20:422-427.

28. Uner A, Ebinc FA, Akyurek N, Unsal D, Mentes BB, Dursun A: Vascular endothelial growth factor, C-erbB-2 and c-erbB-3 expression in colorectal adenoma and adenocarcinoma. Exp Oncol 27:225-228.

29. Schuell B, Gruenberger T, Scheithauer W, Zielinski Ch, Wrba F: Her-2/neu protein expression in colorectal cancer. BMC Cancer 2006, 6:123.

30. Ghaffarzadegan K, Sharifi N, Vosooghynia H, Shakeri T, Ghiasi Moghadam T, Ghanad Kafi Sh, Lari S, Nassiri G: Her-2/neu expression in colon adenocarcinoma and its correlation with clinicopathologic variables. IJBMS 2006, 1:64-69.

31. Beckner ME: Factors promoting tumor angiogenesis. Cancer Invest 1999, 17:594-623.

32. Claffey KP, Robinson GS: Regulation of VEGF/VPF expression in tumor cells: Consequences for tumor growth and metastasis. Cancer Metastasis Rev 1996, 15:165-76.

33. Takahashi $Y$, Kitadai $Y$, Bucana CD, Cleary KR, Ellis LM: Expression of vascular endothelial growth factor and its receptor, KDR, correlates with vascularity, metastasis, and proliferation of human colon cancer. Cancer Res 1995, 55:3964-3968.

34. Kang SM, Maeda K, Onoda N, Chung YS, Nakata B, Nishiguchi Y, Sowa M: Combined analysis of P53 and vascular endothelial growth factor expression in colorectalcarcinoma for determination of tumor vascularity and liver metastasis. Int J Cancer 1997, 74:502-507.

35. Lee JC, Chow NH, Wang ST, Huang SM: Prognostic value of vascular endothelial growth factor expression in colorectal cancer patients. Eur J Cancer 2000, 36:748-53.

36. Petit AM, Rak J, Hung MC, Rockwell P, Goldstein N, Fendly B, Kerbel RS: Neutralizing antibodies against epidermal growth factor and ErbB-2/neu receptor tyrosine kinases down-regulate vascular endothelial growth factor production by tumor cells in vitro and in vivo-Angiogenic implications for signal transduction therapy of solid tumors. Am J Pathol 1997, 151:1523-530.

37. Kuramochi H, Hayashi K, Uchida K, Miyakura S, Shimizu D, Vallböhmer D, Park S, Danenberg KD, Takasaki K, Danenberg PV: Vascular endothelial growth factor messenger RNA expression level is preserved in liver metastases compared with corresponding primary colorectal cancer. Clin Cancer Res 2006, 12:29-33.

38. Mooteri S, Rubin D, Leurgans S, Jakate S, Drab E, Saclarides T: Tumor angiogenesis in primary and metastatic colorectal cancers. Dis Colon Rectum 1996, 39:1073-1080.

39. Berney CR, Yang JL, Fisher RJ, Russell PJ, Crowe PJ: Vascular endothelial growth factor expression is reduced in liver metastasis from colorectal cancer and correlates with urokinase-type plasminogen activator. Anticancer Res 1998, 18:973-977.

40. Do NY, Lim SC, Im TS: Expression of c-erbB receptors, MMPs and VEGF in squamous cell carcinoma of the head and neck. Oncol Rep 2004, 12:229-237.

41. Ochs AM, Wong L, Kakani V, Neerukonda S, Gorske J, Rao A, Riggs M, Ward $H$, Keville L: Expression of Vascular Endothelial Growth Factor and HER2/neu in Stage II Colon Cancer and Correlation with Survival. Clin Colorectal Cancer 2004, 4:262-267.

42. Winlaw DS: Angiogenesis in the Pathobiology and Treatment of Vascular and Malignant Diseases. Ann Thorac Surg 1997, 64:1204-1211.

\section{Pre-publication history}

The pre-publication history for this paper can be accessed here: http://www.biomedcentral.com/1471-2407/11/277/prepub

doi:10.1186/1471-2407-11-277

Cite this article as: Li et al.: Clinicopathological and prognostic significance of HER-2/neu and VEGF expression in colon carcinomas. BMC Cancer 2011 11:277. 